\title{
The outset of the British school of management sociology
}

\author{
Dmitriy N. Sokirkin* \\ Saint Petersburg State University of Architecture and Civil Engineering
}

\begin{abstract}
The purpose of this work is to determine the chronological framework, the features, the main trends and the most prominent representatives of the initial period of creation of the national school of management sociology in Great Britain. In the course of the research process, such general scientific methods as analysis and generalization were used, as well as special methods: historical-genetic and historical periodization. As a result of the study, the data concerning the reasons and prerequisites for the formation of sociological knowledge in the British Isles were obtained. Analysis of the results enabled us to draw conclusions about the importance of the initial period for the subsequent development of the school of management sociology in Great Britain.
\end{abstract}

Currently, sociology is one of the most actively and fruitfully developing humanitarian scientific disciplines. It is in demand by modern society for various reasons of a political, social and economic nature. One of its essential and popular areas is the field of management processes.

At the same time, in every country sociological science has developed along a special path, due to the specifics of the political system, social structure and economic life. As the object of the research, the formation features of the national school of management sociology in Great Britain were selected. The immediate subject of study is the initial period of the aforementioned process associated with the formation of ideas about the social nature of management relations within the framework of philosophical and scientific schools. The purpose of work is to identify the main trends and specific features of the specified period.

Touching upon the question of the degree of scientific elaboration of the chosen topic, it should be noted that, despite obvious interest in the general trends in the development of sociology in Great Britain, so far, no special works have appeared on its structural component, which studies management processes. In turn, the study of the British sociological tradition of management research is of serious scientific interest. Great Britain was at the forefront of the development of capitalism as a socio-economic system, in the conditions of which the problems of social management, characteristic of the modern stage of society development, were already quite clearly manifested [1; p. 28]. In this regard, it should be emphasized that many methods of studying social management, which are

\footnotetext{
* Corresponding author: sokirkin1976@mail.ru
} 
actively used by modern sociology, appeared precisely within the framework of the British scientific school.

Empirical social research, political economy theory and socio-philosophical ideas should be considered as direct predecessors of the British sociological school. Based on this circumstance, the lower chronological boundary of the period under study is determined by the concept development and the conduct of empirical social research in the 17th century, and the upper boundary is the beginning of the classical stage in the history of sociology (mid-19th century).

Interest in the theoretical and empirical study of the principles of management processes originated in the British Isles under the influence of several social factors. These are understood as the most important features of the political, socio-economic and spiritual life of society in the era of modern times. Great Britain was the first in Western Europe to embark on the path of parliamentarism and industrial development. This was facilitated by such political events as the two revolutions that took place in the 17th century (English Bourgeois Revolution and Glorious Revolution), accompanying transformation of religious beliefs, changes in social structure, industrial revolution and urbanization. The country's naval and commercial power was strengthened, and its colonial empire began to form. Such a rapid course of political and socio-economic processes initiated an active study of the principles of society development and interaction of people living in it by statesmen and public figures, philosophers and publicists. This predetermined the significant contribution that was made by the British philosophical and scientific school in the process of forming sociological knowledge. In addition, the socio-political conditions made it possible not only to openly express new ideas, but also to make attempts to implement them in the practice of reforming life.

As noted earlier, the initial period opens in the 17th century with the practice of conducting empirical research, within the framework of which a fairly wide range of social issues was studied. The very process of collecting and subsequent analysis of empirical data in order to improve society management was called 'political arithmetic' [2]. The beginning of this direction was set by the English scientist, the founder of demography as a scientific discipline, J. Graunt (1620-1674) in his work 'Natural and political observations ... in relation to the government'. Having studied the relevant official documents, Gaunt obtained data indicating that appropriate management decisions were needed to solve demographic problems (increase population growth) [3].

The notion 'political arithmetic' was introduced thanks to the publication of the book of the same name by the English statistician and economist W. Petty (1623-1687). Petty was among the first to use statistical methods in studying the nature of social relations, relations between the principles of dividing society into groups (strata) and solution of managerial problems. He demonstrated in practice the role that political arithmetic can play in modernizing the management of various spheres of social life [4].

Another well-known representative of the school of political arithmetic, the English statistician H. King (1650-1712), in 1696 wrote an essay 'Natural and political observations and conclusions about the social situation in England' (published only in 1801). Thus, King anticipated the practice of conducting censuses. In addition, he saw the relationship between crop yields and subsequent administrative regulation of grain prices. This observation formed the basis of the so-called 'Gregory King's law' [5; pp. 70-72].

The astronomer and mathematician E. Halley (1656-1742), who studied the social dynamics of the population of the city of Breslavl, occupies a prominent place in the galaxy of representatives of the classical school of political arithmetic. Halley introduced the concept of probable life expectancy depending on age, which was subsequently widely used in insurance and demographic practice of social management [5; pp. 13-14]. 
The work of political arithmeticists paved the way for broad development of such scientific disciplines as demography and social statistics. The results of the empirical research carried out from now on made it possible not only to assess the state of affairs in the state and society, but also to use the knowledge gained in order to optimize the management of social processes. Anticipating future sociological research, the works of statisticians, economists and demographers of the 17th century reflected the actual situation in British society, while identifying the main trends in the development of social relations, as well as possible ways to improve them. In particular, it was demonstrated that such significant social goals as a high standard of living, effective health care systems, education and social support of the population can be achieved only if the governors agree on the interests of the state and society. Thus, it can be stated that the research carried out by representatives of the school of political arithmetic was devoted to topical problems of the life of society, the solution of which was of decisive importance for the formation of tasks of social management [6; pp. 104-106]. In addition, they served as basis for further formation of special sociological theories of management. Political arithmetic marked in the history of social cognition transition from a simple description of social phenomena to a systematic observation and quantitative expression of their order and sequence and played a significant role in the formation and development of classical sociology [7; pp. 123-127].

Thanks to the emergence of empirical data, progressive-minded representatives of the British political elite and the educated part of society began to change their understanding of the nature of social processes and ways of purposefully managing them. The works of political arithmeticists found a wide response in public opinion and contributed to the adoption of effective management decisions aimed at overcoming social problems in various spheres of society. In order to solve the pressing issues of socio-economic life, it was necessary to first get the most comprehensive idea of the actual state of affairs.

One of the most important results of orienting scientific knowledge towards solving urgent social problems was development of the political economy school [8; p. 189]. In this sense, the publication in 1776 by the professor of logic and moral philosophy A. Smith (1723-1790) of his work 'An Inquiry into the Nature and Causes of the Wealth of Nations' could be recognized as an epoch-making event. The classics of political economy discovered and understood the system of social interaction, which received the name 'market'. Ideas of the classics of English political economy, A. Smith himself, as well as his associate D. Ricardo (1772-1823), acquired such importance in the eyes of contemporaries that the life of society began to be perceived and evaluated through the prism of economic relations. Economics itself acquired the status of an academic discipline.

A. Smith's analysis of capitalism as an economic system gave a huge impetus to the development of sociology [9; p. 7]. One of the main elements of this system, according to Smith, is management - social activity of organizing production in order to obtain maximum surplus value. In accordance with this concept, management is such formalized structure of a rational economic system, which is adapted to achieve technical efficiency by means of human resources coordination. Within the framework of this approach, management is considered as a rationally designed and technology-based mechanism for realizing the desired instrumental values, among which the prevailing individual desire for well-being, as well as the desire inherent in each individual to achieve a higher position in the social structure of society [10; pp. 327-329].

Another basis of British sociology was socio-philosophical ideas about the principles of structure and development of society, which found expression in the works of E. Burke (1729-1797), J. Bentham (1748-1832) and R. Owen (1771-1858).

A politician and publicist of the second half of the 18th century E. Burke considered the individual with all his advantages and disadvantages as the main object of social research. Society itself, according to the thinker, is an organism, parts of which are interdependent 
and evolving in time institutions, each of which performs a certain social function. Burke believed that society should be studied, focusing on socio-cultural factors: traditions, customs, legends, folkways and interests of people. It is these factors that give society and the state an 'organic' (manageable) character.

One of the leading schools of British socio-philosophical thought in the early 19th century was utilitarianism, which was founded by J. Bentham. Bentham believed that human activity is based on the principle of benefit (or usefulness). The criterion of usefulness for Bentham was to ensure the greatest happiness for the greatest number of people, which was justified by him in his work 'Introduction to the principles of morality and law', published in 1789. In this work, Bentham tried to demonstrate the principles on which a reasonable legal system in the state was based, and he proclaimed utility (usefulness) to be the main one. In 1818, he began to develop a 'Constitutional Code' (a draft of a democratic constitution), which assumed the rule of freedom and law, legal equality of citizens, and an effective and responsible administration. In a socioeconomic vein, Bentham supported the principles of economic liberalism put forward in their time by A. Smith and D. Ricardo, believing that any attempt to streamline private initiative and the introduction of labor legislation would lead to an infringement of the freedom of both entrepreneurs and employees.

Bentham was the first to attempt a special study of public opinion, seeing in it an instrument of social control over the activities of the state by the public. He considered the main means of both formation and subsequent expression of public opinion to be the print media (press).

The concept of a 'new society' by the English utopian socialist R. Owen also served as a socio-philosophical basis for the formation of management sociology in Great Britain. According to R. Owen, organization of production should be based on the union of labor, property and costs. It is this approach that will make it possible to put scientific knowledge and machine production at the service of man. Owen's ideas prompted English society to look for ways to solve social problems.

Thus, the socio-political changes in Great Britain itself and in continental Europe that took place in the second half of the 18th century, the scientific and industrial revolution put on the agenda the question of the need to study urgent social problems. The sociophilosophical concepts of Burke, Bentham and Owen gave impetus to the development of new 'sociological' thinking.

The key idea of the founder of sociology, A. Comte (1798-1857) about the need to create a special science about society was supported and worked out by famous British philosophers, representatives, along with Comte himself, of the 'first positivism' - J. St. Mill (1806-1873) and H. Spencer (1820-1903).

An English philosopher, theorist of political and economic liberalism J. St. Mill included sociology, along with psychology and economics, in the system of moral sciences. According to Mill: 'history, with its reasonable study, gives the empirical laws of society. The task of general sociology is to check these laws and relate them to the laws of human nature' [11]. Mill's concept of society, its state and progress, were developed in such works as 'Foundations of Political Economy', 'Reflections on Representative Government', in the treatise 'On Freedom', where he acted as an apologist for liberal democracy and a supporter of moderate social reforms.

The English philosopher H. Spencer, who is considered to be one of the founders of sociology, contributed to the spread of the term 'social institution', using it together with a number of related concepts: 'social relations', 'organization', 'institution (agency)', 'coordinating center (or force)', 'control center', 'system of coercion'. In his opinion, social institutions are a kind of organs of society as a single organism, which make it possible for people to live together and cooperate. 
Spencer's ideological and political views organically blended into the ideas of the English enlightenment of the 18th century and were close to the views of British political economists.

As the analysis has shown, the British management sociology has a rich philosophical and scientific tradition. These traditions have significantly influenced not only the formation of methodology, methods and practice of conducting modern applied sociological research, but also contributed to the development of the theoretical component of sociological science. The works of British sociologists were an important stage in the study and generalization of patterns, forms and methods of purposeful impact on social structures and processes that take place in the state and society. They also contributed to the development of sociology as an independent discipline and to the strengthening of its multidimensional character. All this served to form social knowledge in a new, modern quality, implying an increase in its theoretical significance and practical use.

\section{References}

1. Kultygin V.P., Kuznetsov A.G. Obshchaya sotsiologiya [General sociology]. M.: Nauchnaya kniga Publ., 2004, 282 p.

2. Kuznetsov A.G. Political arithmetic of social management. Vestnik PAGS [Bulletin of PAGS], 2012, No. 1 (30), pp. 123-127.

3. Bulmer M. Development of sociology and empirical social research in Britain. Essays on the history of British sociological research. Cambridge: Cambridge University Press, 1985, pp. 92-98.

4. Petty V. Ekonomicheskiye $i$ statisticheskiye raboty [Economic and statistical works]. Moscow: Progress Publ., 1990, 518 p.

5. International Encyclopedia of the Social Sciences. N.Y.: Humanities Press, 1968, 680 p.

6. Kovalevskiy M.M. Sotsiologiya [Sociology]. SPb.: Peter Publ., 2000, 498 p.

7. Vorontsov A.V., Gromov I.A. Istoriya sotsiologii X1X - nachalo XX veka. Chast 1. Zapadnaya sotsiologiya [History of sociology of the 19th - early 20th century. Part 1. Western sociology]. Moscow: Nauka Publ., 2005, 260 p.

8. Kultygin V.P. Klassicheskaya sotsiologiya [Classical sociology]. M.: Nauka Publ., 2000, $526 \mathrm{p}$.

9. Khrestomatiya po obshchey sotsiologii [Reader on general sociology]. Compiled by Kultygin V.P., Kuznetsov A.G. M.: Nauchnaya kniga Publ., 2004, 212 p.

10. Smith A. Issledovaniya o prirode i prichinakh bogatstv narodov [An inquiry into the nature and causes of the wealth of nations]. SPb.: Peter Publ., 2012, 410 p.

11. Kupriyanov V.A. Rehabilitation of teleology in the philosophy of Baden neokantianism. Filosofiya i kul'tura [Philosophy and Culture], 2017. No. 11, pp. 54-68. DOI: $10.7256 / 2454-0757.2017 .11 .24537$ 